\title{
Nutrition Content, Protein Quality, and Antioxidant Activity of Various Tempeh Gembus Preparations
}

\author{
Diana Nur Afifah, ${ }^{1,2, *}$, Atika Rahma ${ }^{1}$, Shinta Sarining Nuryandari ${ }^{1}$, Lola Alviche ${ }^{1}$, Pipih Indriyamti Hartono ${ }^{1}$, \\ Dewi Marfuah Kurniawati ${ }^{1,2}$, Hartanti Sandi Wijayanti ${ }^{1,2}$, Deny Yudi Fitranti ${ }^{1,2}$, Rachma Purwanti ${ }^{1,2}$ \\ ${ }^{1}$ Department of Nutrition Science, Faculty of Medicine, Universitas Diponegoro, Semarang, Indonesia \\ ${ }^{2}$ CENURE, Centre of Nutrition, Universitas Diponegoro, Semarang, Indonesia \\ *Corresponding author: diananurafifah@live.undip.ac.id
}

Received July 11, 2019; Revised August 15, 2019; Accepted August 23, 2019

\begin{abstract}
Tempeh gembus is a fermented product of tofu processing that offers fairly good nutritional content at an affordable price. However, different food preparation techniques can change the nutrient content of this food product. This study aimed to determine a tempeh gembus preparation method that produces optimal nutrient content, protein quality, and antioxidant activity. Fresh, fried, steamed, and bromelain-added tempeh gembus samples were analyzed for moisture, ash, fat, protein and amino acids, protein digestibility, dietary fiber, isoflavone content, and antioxidant activity and then compared. Fresh tempeh gembus contained $1.87 \%$ fat, $11.09 \%$ dietary fiber, $4.90 \%$ protein, $89.67 \%$ protein digestibility, $14.03 \%$ amino acids, $48.07 \%$ antioxidant activity, $0.05 \%$ genistein, and $0.07 \%$ daidzein. Steamed samples contained less total fat $(1.22 \%)$, dietary fiber $(8.95 \%)$, protein $(3.90 \%)$, protein digestibility (48.68\%), amino acids (13.52\%), and antioxidant activity (39.72\%) but greater genistein (0.07\%) and daidzein $(0.09 \%)$ content versus fresh. Fried samples contained more total fat $(18.23 \%)$, dietary fiber $(22.24 \%)$, antioxidant activity $(61.00 \%)$, and genistein $(0.08 \%)$ versus fresh but lower total protein $(3.92 \%)$, protein digestibility (47.68\%), amino acids (4.10\%), and daidzein (0.10\%). Tempeh gembus with added bromelain contained $1.66 \%$ fat, $9.80 \%$ dietary fiber, $5.12 \%$ protein, $67.16 \%$ protein digestibility, $13.99 \%$ amino acids, $62.04 \%$ antioxidant activity, $0.06 \%$ genistein, and $0.07 \%$ daidzein. Addition of bromelain to tempeh gembus produced optimal nutrient content, protein quality, and antioxidant activity profiles relative to fresh samples, steaming, and frying.
\end{abstract}

Keywords: nutrition content, protein quality, antioxidant activity, tempeh gembus, bromelain

Cite This Article: Diana Nur Afifah, Atika Rahma, Shinta Sarining Nuryandari, Lola Alviche, Pipih Indriyamti Hartono, Dewi Marfuah Kurniawati, Hartanti Sandi Wijayanti, Deny Yudi Fitranti, and Rachma Purwanti, "Nutrition Content, Protein Quality, and Antioxidant Activity of Various Tempeh Gembus Preparations.” Journal of Food and Nutrition Research, vol. 7, no. 8 (2019): 605-612. doi: 10.12691/jfnr-7-8-8.

\section{Introduction}

Tempeh gembus is a source of vegetable protein derived from tofu dregs fermented with Rhizopus oligosporus that have health benefits $[1,2,3,4,5]$ and fairly good nutrient content, including complete macro- and micronutrients [6]. In general, tempeh gembus contains $50 \%$ carbohydrates, $20-30 \%$ protein (39.39\% soluble), $10-20 \%$ fat, including both monounsaturated $(36.53 \%$ oleic acid) and polyunsaturated (26.83\% linoleic acid; $2.46 \%$ linolenic acid) fatty acids (FAs), as well as other minerals and phytochemicals, such as antioxidant [7] and isoflavones $[8,9,10]$. Moreover, the amino acid composition of tempeh gembus is quite complete and can be a source of bioactive peptides [11,12]. Bioactive peptides are specific fragments of primary proteins that are thought to influence physiological function and health [13], largely by readily absorbing free radicals [14]. Bioactive peptides produced by soybeans are known to have various physiological functions, such as antioxidant and anticancer activity.

Tempeh gembus is a very popular fermented food widely consumed in Indonesia due to its affordability and good taste. Tempeh gembus is usually eaten as a side dish or as a snack. [15]. Tempeh gembus is usually consumed after thorough cooking, typically involving heat. Common cooking methods include steaming and frying in oil. Steaming is preferable because it maintains the natural taste, minimizes loss of components and nutrients that cannot withstand high heat [16] and does not increase the fat content [17]. Frying, on the other hand, makes the tempeh gembus more durable and imparts more flavor but does increase the fat content and can damage essential FAs and saturated FA formation in the food ([18]. Furthermore, excess heat reduces the protein and amino acid content in most food products [19]. Another way, tempeh gembus is processed by adding the bromelain enzyme. Bromelain catalyzes the breakdown of proteins into amino acids that are more easily digested by the body [20] Addition of bromelain will produce protein 
hydrolysates that can be utilized as flavor enhancers and improve the functional properties of the food [21,22]. Addition of bromelain can increase the number of available amino acids and may also affect the antioxidant activity and isoflavone content in tempeh gembus [6]. Because the way in which food is prepared can have very different effects on its nutrient content, the present study aimed to determine which tempeh gembus cooking method commonly used in Indonesia results in optimum nutrient content, protein quality, and antioxidant activity.

\section{Materials and Methods}

\subsection{Samples}

Samples of tempeh gembus processed from local soybeans were obtained from Semarang, Central Java, Indonesia. Samples were divided into four groups based on preparation method: unprepared (fresh), fried, steamed, and addition of bromelain. Each sample of tempeh gembus weighed $100 \mathrm{~g}$. Fried samples were prepared in a deep-fat fryer at $160^{\circ} \mathrm{C}$ for $6 \mathrm{~min}$, while steamed samples were prepared at $90^{\circ} \mathrm{C}$ for $10 \mathrm{~min}$ by steam blanching. Samples with added bromelain were pureed in a blender without water before adding the enzyme to a final concentration of 500 ppm bromelain per 100 g tempeh gembus then incubated at $55^{\circ} \mathrm{C}$ for $6 \mathrm{~h}$ in a water bath for enzymatic activation, followed by inactivation at $100^{\circ} \mathrm{C}$ for $10 \mathrm{~min}$.

\subsection{Nutrient Analysis}

\subsubsection{Moisture Content}

Nutritional analysis was performed using several tests. Determination moisture content based in AOAC 2000. [1] Dry the empty dish and lid in the oven at $105^{\circ} \mathrm{C}$ for 3 hours and transfer to desiccator to cool. Weigh the empty dish and lid. Weigh about 3 grams of sample to the dish. Spread the sample to the uniformity. Place the dish with sample in the oven. Dry for 3 hours at $105^{\circ} \mathrm{C}$. After drying, transfer the dish with partially covered lid to the desiccator to cool. Reweigh the dish and its dried sample. Calculate based on formula:

$$
\text { Moisture }(\%)=\frac{(W 1-W 2)}{W 1} \times 100
$$

$\mathrm{W} 1=$ weight $(\mathrm{g})$ of sample before drying

W2=weight (g) of sample after drying

\subsubsection{Ash Content}

Ash was assessed using a drying method. Place about 2 to 4 mgs of sample, accurately weighted, taken in a silica crucible. Spread the material in an even layer and crucible keep in muffle furnace allow the temperature to each $600^{\circ} \mathrm{C}$ and constant for 2 hours, until it is white, indicating the absence of carbon cool in desiccators and weight. Ash can be calculated by using formula: Ash value \% = Weight of Ash/Weight of sample x 100 [2].

\subsubsection{Fat Content}

The multienzyme method (AOAC 1995) was used to analyze dietary fiber. Heat $220 \mathrm{ml}$ ethanol $95 \%$ to $60^{\circ} \mathrm{C}$ and add to the contents of each beaker. Allow the precipitate to settle for at least $1 \mathrm{~h}$ at room temperature and then, decanting under slight vacuum, filter through the prepared glass filter crucibles (wash residues remaining in the beaker into the crucible with small amounts of ethanol 78\%). Prepare the glass filter crucibles used as follows: Heat the thoroughly cleaned glass crucibles for $1 \mathrm{~h}$ at $525^{\circ} \mathrm{C}$, add approximately 1 g Celite ${ }^{\circledR} 545$ (ignited overnight at $525^{\circ} \mathrm{C}$, cooled, and stored in a stoppered container), dry overnight at $105^{\circ} \mathrm{C}$, cool and weigh to the nearest $0.1 \mathrm{mg}$. In order to avoid negative blank values, new crucibles will need to the prepared repeatedly as described. Crucibles should be cooled and stored in a desiccator until required. Wash the residues with $3 \times 15 \mathrm{ml}$ ethanol $78 \%$, then rewash with $2 \times 10 \mathrm{ml}$ ethanol $95 \%$ and $3 \times 10 \mathrm{ml}$ acetone. Dry overnight at $105^{\circ} \mathrm{C}$, cool and weigh to the nearest $0.1 \mathrm{mg}$ [3]

\subsubsection{Protein Content}

Protein content was assessed using the Kjeldahl method. Two grams of powdered sample was digested in a Kjeldahl digestion flask by boiling with $20 \mathrm{ml}$ of concentrated $\mathrm{H}_{2} \mathrm{SO}_{4}$ and a Kjeldahl digestion tablet (catalyst) until the mixture was clear. The digest was filtered into a $250 \mathrm{ml}$ volumetric flask and the solution made up to mark with distilled water and connected for distillation. Ammonia was steam distilled from of the digest to which had been added $50 \mathrm{ml}$ of $45 \%$ sodium hydroxide solution. $150 \mathrm{ml}$ of the distillate was collected in a conical flask containing $100 \mathrm{ml} 0.1 \mathrm{~N} \mathrm{HCl}$ and methyl red indicator. The ammonia that distilled into the receiving conical flask reacted with the acid and the excess acid in the flask was estimated by back titration against $2.0 \mathrm{M} \mathrm{NaOH}$ with colour change from red to yellow (end point). Determinations were made on all reagents alone (blank determinations) [4].

\subsubsection{Protein Digesbility}

Protein digestibility were analyzed by the in vitro method. Specimens were placed on ice and midgut gland were dissected. Samples were immediately stored at $-20^{\circ} \mathrm{C}$. Samples of individuals from the same treatment were pooled. Frozen midgut gland was homogenized in chilled distilled water and centrifuged for $30 \mathrm{~min}$ (10,000 $\mathrm{g}$ at $4^{\circ} \mathrm{C}$ ). The lipid layer was removed and total soluble protein was evaluated in the supernatants, with albumin from chicken egg white (Sigma) as standard. Total proteinase activity was assayed using $1 \%$ azocasein in 50 $\mathrm{mM}$ Tris-HCl buffer, $\mathrm{pH} 7.5$ [5].

\subsubsection{Dietary Fiber Content}

Amino acid and isoflavone (genistein and daidzein) content were analyzed using high performance liquid chromatography (Shimadzu CBM 20A). Fifty milligrams of dried sample were placed in a test tube with ground glass stopper and mixed with $5 \mathrm{~mL}$ of citrate phosphate buffer (pH 4.6) containing $10 \mathrm{mg} \beta$-glucosidase (37 units). The sample was hydrolyzed at $37^{\circ} \mathrm{C}$ for $4 \mathrm{~h}$, and $5 \mathrm{~mL}$ of ethanol was added. After centrifugation for $10 \mathrm{~min}, 8 \mathrm{~mL}$ of the supernatant was dried in a vacuum evaporator. The dietary isoflavones were analyzed using HPLC (Shimadzu, 
Kyoto, Japan) equipped with a diode array detector (260 nm). The compounds were identified by retention times and spectra in comparison with standards and quantified by the peak area [6].

\subsubsection{Amino Acids Content}

FA composition was examined by GC chromatography was performed with a Shimadzu GC2010 chromatography system (Shimadzu Scientific Instruments, Columbia, MA, USA) equipped with an auto sampler and a flame ionization detector. Helium was used as carrier and make-up gas. The injection volume was $1 \mu \mathrm{l}$, which was used with a split ratio of 1:50, or alternative ratios as reported elsewhere in the text. The injection port and detector temperatures were 240 and $250^{\circ} \mathrm{C}$, respectively. The column temperature program was as follows: temperature was held at $30^{\circ} \mathrm{C}$ for $2 \mathrm{~min}$, increased to $180^{\circ} \mathrm{C}$ at $20^{\circ} \mathrm{C} / \mathrm{min}$, held at $180^{\circ} \mathrm{C}$ for $2 \mathrm{~min}$, increased to $207^{\circ} \mathrm{C}$ at $4^{\circ} \mathrm{C} / \mathrm{min}$, held at $207^{\circ} \mathrm{C}$ for 3 min, increased to $220^{\circ} \mathrm{C}$ at $2{ }^{\circ} \mathrm{C} / \mathrm{min}$, held at $220^{\circ} \mathrm{C}$ for 2 min, and then increased to $240^{\circ} \mathrm{C}$ at $2^{\circ} \mathrm{C} / \mathrm{min}$ before finally being held at $240^{\circ} \mathrm{C}$ for $2 \mathrm{~min}$ [7].

\subsubsection{Fatty Acids Content}

Protein fraction profiles were analyzed using SDS-PAGE method with $12 \%$ of acrylamide. Mix the samples with sample buffer (loading buffer). Heat them in boiling water for 5-10 min. Load prepared samples into wells and make sure not to overflow. Don't forget loading protein marker into the first lane. Then cover the top and connect the anodes. Set an appropriate volt and run the electrophoresis when everything's done. As for the total running time, stop SDS-PAGE running when the downmost sign of the protein marker (if no visible sign, inquire the manufacturer) almost reaches the foot line of the glass plate. Generally, about 1 hour for a $120 \mathrm{~V}$ voltage and a $12 \%$ separating gel. For a separating gel posessing higher percentage of acrylamide, the time will be longer [8].

\subsubsection{Genistein and Daidzein Content}

Antioxidant activity was analyzed by the diphenyl picryl hydrazyl hydrate (DPPH) method. Diluted sample $(25 \mu \mathrm{L})$ was mixed with DPPH solution $(40 \mu \mathrm{L}$, $0.4 \mathrm{mg} / \mathrm{mL}$ ) which was served as a control, then, filled up with methanol to $250 \mu \mathrm{L}$. The mixtures were incubated at $37^{\circ} \mathrm{C}$ for $30 \mathrm{~min}$, and then measured at $517 \mathrm{~nm}$. The antioxidant activities were expressed as the percentage of DPPH radical elimination which was calculated from the formula: $\left[\left(\mathrm{A}_{\text {blank }}-\mathrm{A}_{\text {sample }}\right) / \mathrm{A}_{\text {blank }}\right] \times$ $100 \%$, where $A_{\text {blank }}$ and $A_{\text {sample }}$ were the absorbance of black DPPH solution with addition of sample, respectively. Sample concentration providing 50\% inhibition (IC50) was calculated from the graph plotting the inhibition percentage [9]

\subsection{Statistical Analysis}

The present study used a descriptive design to determine the nutritional content and quality of proteins, amino acids, FAs, isoflavones, and antioxidant activity. Each sample group was analyzed in duplicate.

\section{Results and Discussion}

\subsection{Moisture Content}

Table 1 shows steaming produced the highest water (65.22\%) and fried tempeh gembus had the least water (44.65\%). Steaming temperatures cause breakdown of carbohydrates, fats, and proteins, allowing water to bind these damaged compounds [17]. Interestingly, the moisture content of tempeh gembus prepared with addition of bromelain was lower (61.64\%) than fresh samples (63.76\%). This likely occurred via evaporation during the incubation process, together with hydrolysis reactions catalyzed by bromelain that require water as a substrate. It has been shown previously that a decrease in moisture is directly proportional to the concentration of the enzyme added and length of incubation [6]. Furthermore, the high temperatures used in frying cause evaporation of water on the food surface, and absorption of oil by food products is known to replace existing water content [31].

Table 1. Nutrient content and protein quality of various preparations of tempeh gembus

\begin{tabular}{|c|c|c|c|c|}
\hline $\begin{array}{c}\text { Nutrient } \\
\text { content }\end{array}$ & $\begin{array}{c}\text { Fresh } \\
(\mathrm{w} / \mathrm{w} \%)\end{array}$ & $\begin{array}{c}\text { Steamed } \\
(\mathrm{w} / \mathrm{w} \%)\end{array}$ & $\begin{array}{c}\text { Fried } \\
(\mathrm{w} / \mathrm{w} \%)\end{array}$ & $\begin{array}{c}\text { Bromelain } \\
\text { added } \\
(\mathrm{w} / \mathrm{w} \%)\end{array}$ \\
\hline Water & $63.76 \pm 0.14$ & $65.22 \pm 0.22$ & $44.65 \pm 0.35$ & $61.64 \pm 0.17$ \\
\hline Ash & $0.55 \pm 0.01$ & $0.63 \pm 0.01$ & $0.57 \pm 0.00$ & $0.57 \pm 0.00$ \\
\hline Total Fat & $1.87 \pm 0.02$ & $1.22 \pm 0.02$ & $18.23 \pm 0.22$ & $1.66 \pm 0.01$ \\
\hline Total Protein & $4,90 \pm 0.01$ & $3.90 \pm 0.01$ & $3.92 \pm 0.05$ & $5.12 \pm 0.04$ \\
\hline $\begin{array}{c}\text { Protein } \\
\text { Digestibility }\end{array}$ & $89.67 \pm 2.71$ & $48.68 \pm 0.59$ & $47.68 \pm 0.17$ & $67.16 \pm 0.04$ \\
\hline $\begin{array}{c}\text { Total Dietary } \\
\text { Fiber }\end{array}$ & $11.09 \pm 0.20$ & $8.95 \pm 0.10$ & $22.24 \pm 0.00$ & $9.80 \pm 1.11$ \\
\hline
\end{tabular}

\subsection{Ash Content}

As expected, steaming, fried, and bromelain-added preparations tempeh gembus samples had higher ash content $(0.63 \%, 0.57 \%$, and $0.57 \%$, respectively) compared to fresh $(0,55 \%)$. Higher temperatures increase ash content by causing the loss of water in food [10]. Thus, the ash content is likely affected by the moisture present in tempeh gembus samples; the higher the moisture, the lower the ash produced [11].

\subsection{Fat Content}

Table 1 shows the highest fat content was found in fried tempeh gembus (18.23\%). This is not surprising as frying causes water evaporation and absorption of the cooking oil by the food; longer and higher frying temperatures will cause greater oil absorption [12]. Moreover, steamed and bromelain-added preparations had lower fat content $(1.22 \%$ and $1.66 \%$ respectively) than fresh (1.87\%). Higher temperatures can affect the level of fat damage because the properties of fat that cannot heat up can even evaporate into other components [10].

\subsection{Protein Content}

The highest protein content was found in tempeh gembus with added bromelain (5.12\%). Degradation 
of proteins by proteases like bromelain produces peptones, polypeptides, amino acids, ammonia, and other nitrogenous elements [13], which increases the total protein content detected. Steamed and fried tempeh gembus had lower protein content (3.9\% and 3.92\% respectively) than fresh $(4.9 \%)$ likely because proteins coagulate, causing them to lose their binding power by mild denaturation and release any bound water [14]. Frying lowers the protein content as very high temperatures result in the complete destruction of proteins. In addition, the cooking oil used in frying will push out and occupy any empty cavities left by the evaporated water, causing the protein concentration per unit weight of material to decrease [10].

\subsection{Protein Digestibility}

Steaming, fried, and bromelain-added preparations tempeh gembus samples had lower protein digestibility (48.68\%, $47.68 \%$, and $67.16 \%$, respectively) compared to fresh $(89.67 \%)$. Protein digestibility illustrates the content of dissolved amino acids. Protein breakdown into amino acids by enzymes can increase protein digestibility [15]. However, tempeh gembus with added bromelain underwent enzymatic inactivation by heating to $100^{\circ} \mathrm{C}$, a temperature actually results in a decrease in protein and amino acid digestibility. Furthermore, the dissolved protein content will decrease as more bromelain is added due to an increase in hydrolysis reactions which reduce the weight of protein molecules and increase the number of polar clusters. A greater number of hydrolyzed peptide bonds means fewer are counted as soluble proteins [16].

Dissolved proteins, low molecular weight peptides, and free amino acids will dissolve during the steaming process. Such easily denatured protein increases the number of available amino acids and is, therefore, easily digested and absorbed. Those amino acids that are hard to absorb will be eliminated from the body [14]. The decrease in digestibility that occurs in fried tempeh gembus is due to the Maillard reaction which causes crosslinking so that the closed side of the protein can be attacked by enzymes. It may also be due to inhibition of enzyme penetration into the protein substrate [17].

\subsection{Dietary Fiber Content}

The level of dietary fiber obtained from the reduction of residue with protein content and ash content [18]. Frying tempeh gembus resulted in higher dietary fiber (22.24\%) compared to steaming (8.95\%) and bromelain-added (9.8\%) preparations as a result of the Maillard reaction. This nonenzymatic browning reaction occurs between reducing sugars with free amino acid groups or nitrogen components in three main stages. The first involves sugar and amine condensation followed by Amadori rearrangement. In the second stage, sugars become dehydrated and fragmented, and the amino acids are degraded. The third stage includes condensation of aldehydes, formation of heterocyclic nitrogen compounds [19], and change of carbonyl compounds into compounds of high molecular weight [20].

The reduction of dietary fiber in steamed tempeh gembus samples is due to hydrolysis, which breaks down polymers (polysaccharides) into monomers (monosaccharides) involving water. Moreover, heating can speed up this reaction because it is endothermic [21]. The level of dietary fiber was also lowered by addition of bromelain compared to fresh tempeh gembus because inactivation of the enzyme involves warming resulting in hydrolysis.

\subsection{Amino Acid Content}

All of the tempeh gembus preparations contained 15 amino acids (9 essential, 6 nonessential). Table 2 shows the amino acid composition of each of the various tempeh gembus preparations on a dry basis. Overall, fresh, steamed, and bromelain-added preparations had the highest levels of both essential and nonessential amino acids.

The total amount of amino acids in fresh tempeh gembus on a dry bases was highest. Steaming lowered the total amino acid content versus fresh because this process leads to protein denaturation into amino acids. The amino acids quickly dissolve in the surrounding water, which is eventually discharged from the food as it condenses, thereby reducing the amount of amino acids present [22][24]. Frying, however, produced the lowest total amino acid content of the four preparation methods because the high temperatures used in this cooking method damage proteins and amino acids irreversibly. Frying at temperatures around $160{ }^{\circ} \mathrm{C}$ can result in a significant decrease in nutrient content due to the significant loss of protein and amino acid content, among other issues [10].

Table 2. Amino acid composition of various tempeh gembus preparations

\begin{tabular}{|l|c|c|c|c|}
\hline $\begin{array}{c}|c| \\
\text { Amino acid } \\
\text { type }\end{array}$ & $\begin{array}{c}\text { Fresh } \\
(\mathrm{w} / \mathrm{w} \%)\end{array}$ & $\begin{array}{c}\text { Steamed } \\
(\mathrm{w} / \mathrm{w} \%)\end{array}$ & $\begin{array}{c}\text { Fried } \\
(\mathrm{w} / \mathrm{w} \%)\end{array}$ & $\begin{array}{c}\text { Bromelain } \\
\text { added } \\
(\mathrm{w} / \mathrm{w} \%)\end{array}$ \\
\hline Essential & $0.47 \pm 0.03$ & $0.91 \pm 0.66$ & $0.09 \pm 0.08$ & $0.44 \pm 0.07$ \\
\hline Histidine & $0.71 \pm 0.06$ & $0.70 \pm 0.03$ & $0.23 \pm 0.00$ & $0.76 \pm 0.11$ \\
\hline Threonine & $0.15 \pm 0.06$ & $0.14 \pm 0.09$ & $0.05 \pm 0.03$ & $0.20 \pm 0.03$ \\
\hline Methionine & $0.97 \pm 0.11$ & $0.88 \pm 0.01$ & $0.28 \pm 0.01$ & $0.94 \pm 0.13$ \\
\hline Valine & $0.82 \pm 0.12$ & $0.77 \pm 0.00$ & $0.24 \pm 0.03$ & $0.76 \pm 0.11$ \\
\hline Phenylalanine & $0.89 \pm 0.13$ & $0.84 \pm 0.01$ & $0.27 \pm 0.01$ & $0.87 \pm 0.11$ \\
\hline Isoleucine & $1.27 \pm 0.18$ & $1.20 \pm 0.04$ & $0.38 \pm 0.03$ & $1.17 \pm 0.13$ \\
\hline Leucine & $1.05 \pm 0.08$ & $0.45 \pm 0.20$ & $0.22 \pm 0.00$ & $0.91 \pm 0.04$ \\
\hline Lysine & $0.64 \pm 0.07$ & $0.64 \pm 0.04$ & $0.20 \pm 0.02$ & $0.37 \pm 0.08$ \\
\hline Arginine & 1.49 & $13.52 \pm 0.42$ & $4.10 \pm 0.13$ & $13.99 \pm 2.12$ \\
\hline Nonessential & & & & \\
\hline Aspartic acid & $1.67 \pm 0.14$ & $1.69 \pm 0.01$ & $0.49 \pm 0.01$ & $1.62 \pm 0.22$ \\
\hline Glutamic acid & $2.32 \pm 0.21$ & $2.35 \pm 0.01$ & $0.70 \pm 0.01$ & $2.53 \pm 0.36$ \\
\hline Serine & $0.81 \pm 0.04$ & $0.77 \pm 0.03$ & $0.24 \pm 0.00$ & $0.84 \pm 0.12$ \\
\hline Glycine & $0.72 \pm 0.08$ & $0.71 \pm 0.03$ & $0.22 \pm 0.02$ & $0.74 \pm 0.20$ \\
\hline Alanine & $0.93 \pm 0.10$ & $0.87 \pm 0.01$ & $0.27 \pm 0.01$ & $1.05 \pm 0.19$ \\
\hline Tyrosine & $0.60 \pm 0.07$ & $0.57 \pm 0.03$ & $0.18 \pm 0.01$ & $0.75 \pm 0.21$ \\
\hline $\begin{array}{l}\text { Amino Acid } \\
\text { Total }\end{array}$ & $14.03 \pm$ & 13 & \\
\hline
\end{tabular}

In contrast, addition of bromelain increased the level of protein and some amino acids (threonine, methionine, glutamate, serine, glycine, alanine, and tyrosine) in tempeh gembus samples. While the presence of bromelain protein itself likely contributed to the increase in total 
protein, addition of higher enzyme concentrations and longer incubation periods will lead to greater proteolytic breakdown of the food [25], thereby increasing the total protein and amino acid content [16]. Furthermore, steamed and bromelain-added samples had amino acid contents that did not differ much from fresh, indicating these preparation methods are best for maintaining optimal protein and amino acid nutritional content.

\subsection{Fatty Acids Content}

Table 3 show that the four tempeh gembus preparations contained saturated, monounsaturated, and polyunsaturated FAs. Palmitic acid (0.119\%) and stearic acid (0.05\%) were found to be the dominant saturated FAs in fresh tempeh gembus but were lowest in steamed samples. This is not surprising as steaming is a recommended cooking method for processing high-fat content [17]. Although fried tempeh gembus had the highest palmitic acid (14.744\%) and stearic acid (1.247\%) content relative to the other preparation methods, this was a direct result of the high saturated fat content of the cooking oil [17,32,46]. For example, the palmitic and stearic acid content of palm oil is about $41.8-45.8 \%$ and $4.2-5.1 \%$. Moreover, the level of palmitic and stearic acids in tempeh gembus with added bromelain was lower $(0.088 \%$ and $0.036 \%$ respectively) than in fried and fresh samples but higher than in steamed. This happened because bromelain works to break lipoprotein bonds in fatty emulsions; a higher bromelain concentration results in more broken lipoprotein bonds and therefore, more fats in the form of oil extracted from the food [26].

The dominant unsaturated FAs in fresh tempeh gembus were oleic (monounsaturated), linoleic (polyunsaturated), and linolenic (polyunsaturated) acids. Steaming produced the lowest levels of these three FAs of all of the preparation methods due to the nature of this cooking process as discussed above. The levels of these unsaturated FAs in tempeh gembus with added bromelain were lower than in fried and fresh samples but not steamed. Higher temperatures are known damage FAs in foods [18], and essential FAs are isomerized when heated in alkaline solutions, making them sensitive to light, temperature, and oxygen. Oxidation reactions that occur during heating cause reduction of unsaturated fatty acid [17]. Because the oxidation rate is directly proportional to the degree of unsaturation, linolenic acid (3 double bonds) is more easily oxidized than linoleic (2 double bonds) and oleic (1 double bond) [32]. Finally, fried tempeh gembus contained more oleic, linoleic, and linolenic acids than the other preparations stemming from the cooking oil; the oleic, linoleic, and linolenic acid content in coconut oil is $37.3-40.8 \%, 9.23 \%$, and $0.0-0.6 \%$, respectively $[48,49]$. FA's found in fried samples that were not present in any of the other three preparations (pentadecanoic and cis-10-heptadecanoic acids) were likely inherent in the cooking oil and not the tempeh gembus itself.

Table 3. Fatty acid composition in various preparations of tempeh gembus

\begin{tabular}{|c|c|c|c|c|}
\hline Fatty acid type & $\begin{array}{c}\text { Fresh } \\
(\mathrm{w} / \mathrm{w} \%)\end{array}$ & $\begin{array}{l}\text { Steamed } \\
(\mathrm{w} / \mathrm{w} \%)\end{array}$ & $\begin{array}{c}\text { Fried } \\
(\mathrm{w} / \mathrm{w} \%)\end{array}$ & $\begin{array}{c}\text { Bromelain added } \\
\text { (w/w \%) }\end{array}$ \\
\hline \multicolumn{5}{|l|}{ Saturated } \\
\hline Lauric acid & & $0.000 \pm 0.00$ & $0.081 \pm 0.003$ & $0.000 \pm 0.00$ \\
\hline Myristic acid & $0.001 \pm 0.00$ & $0.001 \pm 0.00$ & $0.316 \pm 0.014$ & $0.001 \pm 0.00$ \\
\hline Pentadecanoic acid & $0.000 \pm 0.00$ & $0.000 \pm 0.00$ & $0.013 \pm 0.00$ & $0.000 \pm 0.00$ \\
\hline Palmitic acid & $0.119 \pm 0.001$ & $0.073 \pm 0.008$ & $14.744 \pm 0.522$ & $0.088 \pm 0.018$ \\
\hline Heptadeca-noic acid & $0.001 \pm 0.00$ & $0.001 \pm 0.00$ & $0.031 \pm 0.00$ & $0.001 \pm 0.00$ \\
\hline Stearic acid & $0.050 \pm 0.00$ & $0.029 \pm 0.003$ & $1.247 \pm 0.063$ & $0.036 \pm 0.007$ \\
\hline Arachidic acid & $0.003 \pm 0.00$ & $0.002 \pm 0.00$ & $0.101 \pm 0.01$ & $0.002 \pm 0.00$ \\
\hline Heneicosa-noic acid & $0.000 \pm 0.00$ & $0.000 \pm 0.00$ & $0.000 \pm 0.00$ & $0.000 \pm 0.00$ \\
\hline Behenic acid & $0.004 \pm 0.00$ & $0.002 \pm 0.00$ & $0.018 \pm 0.00$ & $0.003 \pm 0.00$ \\
\hline Tricosa-noic acid & $0.001 \pm 0.00$ & $0.000 \pm 0.00$ & $0.000 \pm 0.00$ & $0.000 \pm 0.00$ \\
\hline Lignoseric acid & $0.004 \pm 0.00$ & $0.003 \pm 0.00$ & $0.024 \pm 0.004$ & $0.002 \pm 0.003$ \\
\hline \multicolumn{5}{|l|}{ Monounsaturated } \\
\hline Palmitoleic acid & $0.001 \pm 0.00$ & $0.001 \pm 0.00$ & $0.053 \pm 0.001$ & $0.001 \pm 0.00$ \\
\hline Cis-10-Heptadeca-noic acid & $0.001 \pm 0.00$ & $0.000 \pm 0.00$ & $0.009 \pm 0.00$ & $0.000 \pm 0.00$ \\
\hline Oleic acid & $0.273 \pm 0.006$ & $0.166 \pm 0.021$ & $17.287 \pm 0.666$ & $0.194 \pm 0.045$ \\
\hline Elaidic acid & $0.001 \pm 0.00$ & $0.000 \pm 0.00$ & $0.026 \pm 0.00$ & $0.001 \pm 0.00$ \\
\hline \multicolumn{5}{|l|}{ Polyunsaturated } \\
\hline Linoleic acid & $0.598 \pm 0.007$ & $0.306 \pm 0.026$ & $4.866 \pm 0.214$ & $0.420 \pm 0.099$ \\
\hline Linolelai-dic acid & $0.001 \pm 0.00$ & $0.000 \pm 0.00$ & $0.000 \pm 0.00$ & $0.000 \pm 0.00$ \\
\hline$\gamma$-linolenic acid & $0.008 \pm 0.001$ & $0.005 \pm 0.00$ & $0.000 \pm 0.00$ & $0.007 \pm 0.001$ \\
\hline Linolenic acid & $0.040 \pm 0.00$ & $0.017 \pm 0.00$ & $0.134 \pm 0.006$ & $0.026 \pm 0.005$ \\
\hline Cis-11.14 Eicosedie-noic acid & $0.001 \pm 0.00$ & $0.000 \pm 0.00$ & $0.022 \pm 0.008$ & $0.001 \pm 0.00$ \\
\hline Total fatty acids & $1.275 \pm 0.042$ & $0.765 \pm 0.066$ & $43.915 \pm 0.665$ & $0.968 \pm 0.197$ \\
\hline Total fat & $1.47 \pm 0.08$ & $0.96 \pm 0.07$ & $49.49 \pm 0.40$ & $1.19 \pm 0.21$ \\
\hline
\end{tabular}


Table 4. Antioxidant activity and isoflavone content of various tempeh gembus preparations

\begin{tabular}{|l|c|c|c|}
\hline Preparation type & Genistein (w/w \%) & Daidzein (w/w \%) & Antioxidant activity (\%) \\
\hline Fresh & $0.05 \pm 0.00$ & $0.07 \pm 0.00$ & $48.07 \pm 11.03$ \\
\hline Steamed & $0.07 \pm 0.00$ & $0.09 \pm 0.00$ & $39.72 \pm 3.12$ \\
\hline Fried & $0.08 \pm 0.00$ & $0.10 \pm 0.00$ & $61.00 \pm 7.05$ \\
\hline Bromelain added & $0.06 \pm 0.00$ & $0.07 \pm 0.00$ & $62.04 \pm 0.03$ \\
\hline
\end{tabular}

\subsection{Genistein and Daidzein Isoflavone Content}

Isoflavones are one of the many flavonoid groups present in bean crops, such as soybeans [50]. Soybeans are known to contain 12 isoflavone derivatives consisting of three types of aglycones and nine glucosides. Fermented soybean products, such as tempeh gembus, have higher isoflavone-aglycone content than isoflavone-glucosides. Genistein and daidzein are isoflavones derived from multiple aglycones contained in soybeans and act as phytoestrogens with antioxidant activity $[51,52,53]$

Table 4 shows genistein and daidzein isoflavone content of each tempeh gembus preparation. The content of genistein $(0.08 \%)$ and daidzein $(0.10 \%)$ was highest in fried tempeh gembus, followed by steamed $(0.07 \%$ and $0.09 \%$, respectively), bromelain-added $(0.06 \%$ and $0.07 \%$, respectively), and fresh $(0.05 \%$ and $0.07 \%$, respectively) samples. Heat and enzymatic treatment are known to increase soy isoflavone levels [54]. During the bromelain incubation process, hydrolysis of isoflavone-glucosides occurs creating isoflavone-aglycones due to $\beta$-glucosidase. $\beta$-Glucosidase works optimally in acidic conditions which is promoted by bromelain's acidic properties ( $\mathrm{pH}$ 4.11) [9].

Fresh tempeh gembus also has lower genistein and daidzein content than soybean tempeh $(0.68 \%$ and $0.44 \%$, respectively). This difference in nutrient content between the two types of tempeh is because tempeh gembus is made from the residue of the tofu making process $[55,56]$.

\subsection{Antioxidant Activity}

Interestingly, Table 4 shows the different reactions that occurred with each preparation method affected the antioxidant activity of the tempeh gembus differently. The highest percentage of antioxidant activity was found in tempeh gembus with added bromelain (62.04\%). This is because enzymatic hydrolysis caused by bromelain produces bioactive peptides in soybean protein which play roles in increasing antioxidant activity $[13,57,58]$.

Although fried tempeh gembus had higher (61.00\%) antioxidant activity than fresh, it was still lower than in samples with added bromelain. Heating leads to nonenzymatic browning (Maillard) reactions between amino acids and glucose that can increase antioxidant activity. For example, melanoidin compounds are a group of Maillard reaction products that have a role in increasing antioxidant activity [59,60]. Steamed tempeh gembus, however, had the lowest (39.72\%) antioxidant activity of all of the preparation methods. This is likely the result of oxidation reactions that occur during the steaming process, which can degrade antioxidants contained within the food [27].
The percentage of antioxidant activity in fresh tempeh gembus (48.07\%) was lower than that of soybeans (72.08\%), according to a previous study. Protein content has been shown to affect antioxidant activity in foods. ${ }^{40}$ Considering the total protein content in fresh tempeh gembus is relatively low, previous research analyzing the composition of nutrients during the process of making tempeh gembus has shown there is a decrease of total amino acids from $34.95 \%$ in soybean to $6.7 \%$ in tempeh gembus [10].

\section{Conclusions}

The present study revealed that addition of bromelain to tempeh gembus had an optimal effect on the nutrient content, protein quality, and antioxidant activity of this popular Indonesian food product versus steamed, fried, and fresh preparations.

\section{Acknowledgements}

There is no conflict interest in this study.

\section{References}

[1] P. K. Dewi, D. N. Afifah, N. Rustanti, M. Sulchan, and Gemala Anjani, "The Effect of Tempeh Gembus Variations to Serum Levels of High Sensitivity C-Reactive Protein (hsCRP) and Serum Levels of Fibrinogen of Sprague Dawley Rats with Aterogenic Diet,” Rom J Diabetes Nutr Metab Dis, vol. 25, no. 1, pp. 091-097, 2018.

[2] D. N. Afifah, N. Nabilah, G. T. Supraba, S. N. Pratiwi, Nuryanto, and M. Sulchan, "The Effects of Tempeh Gembus, an Indonesian Fermented Food, on Lipid Profiles in Women with Hyperlipidemia," Curr. Nutr. Food Sci., vol. 14, pp. 1-9, 2018.

[3] D. Wang et al., "An Efficient Method for the Preparative Isolation and Purification of Flavonoid Glycosides and Prep-HPLC Guided by DPPH-HPLC Experiments,” Molecules, vol. 22, p. 229, 2017.

[4] D. N. Afifah, M. Sulchan, D. Syah, Yanti, M. T. Suhartono, and J. H. Kim, "Purification and characterization of a fibrinolytic enzyme from Bacillus pumilus 2.g isolated from gembus an Indonesian fermented food,” Korean Soc. Food Sci. Nutr., vol. 19, no. 3, pp. 213-219, 2014.

[5] D. N. Afifahh, N. R. Anjani, D. Syah, Yanti, and M. T. Suhartono, "Proteomics study of extracellular fibrinolytic proteases from Bacil-lus licheniformis RO3 and Bacillus pumilus 2.g isolated from In-donesian fermented food.," IOP Conf Ser. Earth Environ. Sci., vol. 55, pp. 1-10, 2017.

[6] J. C. Wijaya and Y. Yunianta, "The Effect of Different Bromelain Enzyme Concentration and Incubation Period toward Tempeh Gembus's Chemical and Organoleptical Characteristics,” J. Pangan dan Agroindustri, vol. 3, no. 1, pp. 96-106, 2015.

[7] R. K. Agustina, F. F. Dieny, N. Rustanti, G. Anjani, and D. N. Afifah, "Antioxidant activity and soluble protein content of tempeh gembus hydrolysate,” Hiroshima J. Med. Sci., vol. 67, pp. 1-7, 2018 
[8] W. C. Vong and S.-Q. Liu, "Biovalorisation of okara (soybean residue) for food and nutrition," Trends Food Sci. Technol., vol. 52, pp. 139-147, Apr. 2016.

[9] T. Purwoko, "Kandungan Isoflavon Aglikon pada Tempe Hasil Fermentasi Rhizopus microsporus var. oligosporus: Pengaruh Perendaman,” BioSMART, vol. 6, no. 2, pp. 85-87, 2004.

[10] R. N. S. Damanik, D. Pratiwi, N. Widyastuti, N. Rustanti, G. Anjani, and D. Afifah, "Nutritional Composition Changes During Tempeh Gembus Processing," IOP Conf. Ser. Earth Environ. Sci., vol. 116, 2018.

[11] M. Sulchan and M. I. Rukmi, "Effect of tempe gembus on cholesterol profile in hyperlipidemic rats," Med. J. Indones., vol. 16, no. 4, pp. 205-211, 2013.

[12] M. Sulchan and N. Endang, "Nilai Gizi dan Komposisi Asam Amino Tempe Gembus serta Pengaruhnya terhadap Pertumbuhan Tikus," Maj. Kedokt. Indones., vol. 57, no. 3, pp. 80-85, 2007.

[13] B. P. Singh, S. Vij, and S. Hati, "Functional Significance of Bioactive Peptides Derived from Soybean,” Peptides, vol. 54, pp. 171-179, Apr. 2014.

[14] M. F. Sbroggio, M. S. Montilha, V. R. G. de Figueiredo, S. R. Georgetti, and L. E. Kurozawa, "Influence of the degree of hydrolysis and type of enzyme on antioxidant activity of okara protein hydrolysates," Food Sci. Technol., vol. 36, no. 2, pp. 375-381, 2016.

[15] D. N. Afifah, G. Nugrahani, V. N. Hastuti, and F. Arifan, "The characteristics of Kerupuk Gembus," IOP Conf. Ser. Earth Environ. Sci., vol. 292, no. 1, 2019.

[16] Zakaria, A. Tamrin, Nursalim, and Irmayanti, "Pengaruh perlakuan blanching terhadap kadar $\beta$-Karoten pada pembuatan tepung daun kelor (Moringa oleifera)," Media Gizi Pangan, vol. 9, no. 1, pp. 23-28, 2015.

[17] S. Sulthoniyah, T. Sulistiyati, and E. Suprayitno, "Pengaruh suhu pengukusan terhadap kandungan gizi dan organoleptik abon ikan gabus (Ophiocephalus striatus)," THPi Student J., vol. 1, no. 1, pp. 33-45, 2013.

[18] M. Naseri, E. Abedi, B. Mohammadzadeh, and A. Afsharnaderi, "Effect of frying in different culinary fats on the fatty acid composition of silver carp," Food Sci. Nutr., vol. 1, no. 4, pp. 292-297, 2013.

[19] S. Purwaningsih, E. Salamah, and G. P. Apriyana, "Profil Protein dan Asam Amino Keong Ipong-Ipong (Fasciolaria Salmo) pada Pengolahan yang Berbeda," J. Gizi dan Pangan, vol. 8, no. 1, pp. 77-82, Nov. 2013.

[20] Subandiyono, S. Hastuti, and R. A. Nugroho, "Feed utilization efficiency and growth of Java barb ( Puntius javanicus ) fed on dietary pineapple extract," AACL Bioflux, vol. 11, no. 2, pp. 309-318, 2018.

[21] H. Kristinsson, "Aquatic Food Protein Hydrolysates," in Maximising the Value of Marine By Product, F. Shahidi, Ed. Boca Raton: CRC Press, 2007.

[22] V. Venugopal, Seafood Processing: Adding Value Trough Quick Freezing, Retortable Packaging, and Chilling. Boca Raton: CRC Press, 2006.

[23] V. M. da Silva, L. A. S. e J. B. de Andrade, M. C. da C. Veloso, and G. V. Santos, "Determination of moisture content and water activity in algae and fish by thermoanalytical techniques," Quim. Nov., vol. 31, no. 4, pp. 901-905, 2008.

[24] M. Sonkamble and N. Pandhure, “Art20176072,” Int. J. Sci. Res., vol. 6, no. 8, pp. 936-938, 2015.

[25] AOAC, Official Methods of Analysis of The Association of Official Analytical Chemists. Washington DC, USA, 1995.

[26] A. M. Magomya, D. Kubmarawa, J. A. Ndahi, and G. G. Yebpella, "Determination Of Plant Proteins Via The Kjeldahl Method And Amino Acid Analysis: A Comparative Study,” Int. J. Sci. Technol. Res., vol. 3, no. 4, pp. 68-72, 2014.

[27] A. V. F. Gimenez, A. C. Díaz, S. M. Velurtas, and J. L. Fenucci, "In vivo and In vitro protein digestibility of formulated feeds for Artemesia longinaris (Crustacea, Penaeidae)," Brazilian Arch. Biol. Technol., vol. 52, no. 6, pp. 1379-1386, 2009.

[28] A. Miura, C. Sugiyama, H. Sakakibara, K. Simoi, and T. Goda, "Journal of Nutrition \& Intermediary Metabolism Bioavailability of iso $\mathrm{fl}$ avones from soy products in equol producers and nonproducers in Japanese women," J. Nutr. Intermed. Metab., vol. 6, pp. 41-47, 2016.

[29] Z. Xu, K. Harvey, and T. Pavlina, "An Improved Method for Determining Medium- and Long-Chain FAMEs Using Gas
Chromatography An Improved Method for Determining Medium- and Long-Chain FAMEs Using Gas Chromatography," Lipids, vol. 45, pp. 3382-7, 2010.

[30] B. Hames, Gel Electrophoresis of Proteins, 3rd editio. New York: Oxford university press, 1998.

[31] P. Bouchon, "Understanding oil absorption during deep-fat frying," Adv. Food Nutr. Res., vol. 57, pp. 209-234, Feb. 2009.

[32] D. Sundari, A. Almasyhuri, and A. Lamid, "Pengaruh Proses Pemasakan Terhadap Komposisi Zat Gizi Bahan Pangan Sumber Protein,” Media Penelit. dan Pengemb. Kesehat., vol. 25, no. 4, pp. 235-242, Dec. 2015.

[33] Ratnaningsih, B. Rahardjo, and Suhargo, "Kajian penguapan air dan penyerapan minyak pada penggorengan ubi jalar (Ipomoea batatas L) dengan metode deep-fat frying,” Agritech, vol. 27, no. 1, pp. 27-32, 2007.

[34] O. L. Tavano, "Journal of Molecular Catalysis B: Enzymatic Protein hydrolysis using proteases: An important tool for food biotechnology,” J. Mol. Catal. B. Enzym., vol. 90, pp. 1-11, 2013.

[35] J. L. England and G. Haran, "Role of Solvation Effects in Protein Denaturation: From Thermodynamics to Single Molecules and Back,” Annu Rev Phys Chem, vol. 62, pp. 257-277, 2011.

[36] Muthmainna, S. Mulyani, and Supriadi, "Pengaruh Waktu Fermentasi Terhadap Kadar Protein dari Tempe Biji Buah Lamtoro Gung (Leucaena leucocephala),” J. Akad. Kim., vol. 5, no. 1, pp. 50-54, 2016.

[37] N. Palupi and E. Prangdimurti, "Pengaruh Pengolahan terhadap Nilai Gizi Pangan," in Modul e-Learning ENBP, Bogor, 2007, pp. 1-14.

[38] J. Ceirwyn, Analytical chemistry of foods. New York: Aspen Publishers Inc, 1999.

[39] K. Bunko and J. F. Kennedy, "The Maillard Reaction: Chemistry, Biochemistry and Implications," Int J Biol Macromol, vol. 41, no. 3, p. 358, Aug. 2007.

[40] T. Yokotsuka, Soy Sauce Biochemistry, vol. 30. 1986.

[41] Nurhidajah, M. Astuti, Sardjono, A. Murdiati, and Y. Marsono, "Kadar Serat Pangan dan Daya Cerna Pati Nasi Merah yang Diperkaya Kappa-Karagenan dan Ekstrak Antosianin dengan Variasi Metode Pengolahan,” Universitas Muhammadiyah Semarang, 2015.

[42] A. Jacoeb, Nurjanah, and L. Lingga, "Karakteristik protein dan asam amino daging rajungan (Portunus pelagicus) akibat pengukusan,” JPHPI, vol. 15, no. 2, pp. 156-163, 2012.

[43] Ö. Özden and N. Erkan, "A preliminary study of amino acid and mineral profiles of important and estimable 21 seafood species," Br. Food J., vol. 113, no. 4, pp. 457-469, Apr. 2011.

[44] S. Sitompul, "Analisis asam amino dalam tepung ikan dan bungkil kedelai,” Bul. Tek. Pertan., vol. 9, no. 1, pp. 33-37, 2004.

[45] I. Purwaningsih, "Potensi Enzim Bromelin Sari Buah Nanas (ananas comosus l.) Dalam Meningkatkan Kadar Protein Pada Tahu," J. Teknol. Lab., vol. 6, no. 1, p. 39, 2017.

[46] A. M. Jacoeb, P. Suptijah, and W. A. Kristantina, "Komposisi Asam Lemak, Kolesterol, dan Deskripsi Jarinagn Fillet Ikan Kakap Segar dan Goreng,” J. Pengolah. Has. Perikan. Indones., vol. 18, no. 1, pp. 98-107, 2015.

[47] F. Salahudin and N. Supriyatna, "Ekstraksi minyak kelapa secara fermentasi untuk mempertahankan mutu asam lemak rantai sedang,” Biopropal Ind., vol. 5, no. 1, pp. 23-28, 2014.

[48] I. Astiana, Nurjanah, R. Suwandi, A. A. Suryani, and T. Hidayat, "Pengaruh penggorengan belut sawah (Monopterus albus) terhadap komposisi asam amino, asam lemak, kolesterol dan mineral,” Depik, vol. 4, no. 1, pp. 49-57, 2015.

[49] N. B. Falistin, W. F. Ma'ruf, and E. N. Dewi, "Pengaruh tahapan pengolahan terhadap kualitas kandungan lemak bandeng (Chanos chanos Forks) presto goreng,” J. Pengolah. dan Bioteknol. Has. Perikan., vol. 4, no. 2, pp. 93-99, 2015.

[50] E. Yusnawan, "The diversity of secondary metabolites in Indonesian soybean genotypes,” Biodiversitas, vol. 17, no. 2, pp. 704-710, 2016.

[51] G. Szymczak, M. Wójciak-Kosior, I. Sowa, K. Zapała, M. Strzemski, and R. Kocjan, Evaluation of isoflavone content and antioxidant activity of selected soy taxa, vol. 57. 2017.

[52] P. Rajendran et al., "Antioxidants and Human Diseases," Clin. Chim. Acta, vol. 436, pp. 332-347, Jun. 2014.

[53] J. Anderson, C. Hil, and N. Carolina, Phytoestrogens and Health. Toronto: AOCS Press, 2002. 
[54] J. H. Lee et al., "Changes in phenolic compounds (Isoflavones and Phenolic acids) and antioxidant properties in high-protein soybean (Glycine max L., cv. Saedanbaek) for different roasting conditions," J. Korean Soc. Appl. Biol. Chem., vol. 56, no. 5, pp. 605-612, 2013.

[55] A. Noviana, F. Dieny, N. Rustanti, G. Anjani, and D. N. Afifah, "Antimicrobial activity of tempeh gembus hydrolyzate," in IOP Conference Series: Earth and Environmental Science, 2018, vol. 116, p. 12044.

[56] R. Kurniasari, M. Sulchan, D. N. Afifah, G. Anjani, and N Rustanti, "Influence variation of tempe gembus (an Indonesian fermented food) on homocysteine and malondialdehyde of rats fed an atherogenic diet," Rom. J. Diabetes, Nutr. Metab. Dis., vol. 24, no. 3, pp. 203-211, 2017.

[57] B. F. Gibbs, A. Zougman, R. Masse, and C. Mulligan, "Production and characterization of bioactive peptides from soy hydrolysate and soy-fermented food,” Food Res. Int., vol. 37, no. 2, pp. 123-131, Mar. 2004.

[58] E. Mejia and B. de Lumen, "Soybean bioactive peptides: A new horizon in preventing chronic diseases," Sex. Reprod. Menopause, vol. 4, no. 2, pp. 91-95, Oct. 2006.

[59] K.-H. Wagner, D. S, H. M, S. W, and I. Elmadfa, "Antioxidative potential of melanoidins isolated from a roasted glucose-glycine model," Food Chem., vol. 78, pp. 375-382, Aug. 2002.

[60] K. Pelealu, J. Pontoh, and E. Suryanto, "Pengaruh Pemanasan Terhadap Aktivitas Antioksidan Dalam Pembuatan Gula Aren," J. Kim., vol. 4, no. 2, pp. 60-65, 2011.

[61] D. Pramita, S. Handajani, and D. Rachmawanti, "Pengaruh teknik pemanasan terhadap kadar asam fitat dan aktivitas antioksidan koro benguk (Mucuna pruriens), koro glinding (Phaseolus lunatus), dan koro pedang (Canavalia ensiformis)," Biofarmasi, vol. 6, no. 2, pp. 36-44, 2018

(C) The Author(s) 2019. This article is an open access article distributed under the terms and conditions of the Creative Commons Attribution (CC BY) license (http://creativecommons.org/licenses/by/4.0/). 